19 Revue d'histoire du XIXe siècle

Société d'histoire de la révolution de 1848 et des

révolutions du XIXe siècle

$5 \mid 1989$

Histoires de centenaires, ou le devenir des révolutions

\title{
1830-1930 : le centenaire des Trois glorieuses en France
}

Fernand Rude

\section{OpenEdition \\ Journals}

Electronic version

URL: http://journals.openedition.org/rh19/32

DOI: $10.4000 /$ rh 19.32

ISSN: $1777-5329$

\section{Publisher}

La Société de 1848

\section{Printed version}

Date of publication: 1 June 1989

ISSN: 1265-1354

\section{Electronic reference}

Fernand Rude, «1830-1930 : le centenaire des Trois glorieuses en France », Revue d'histoire du XIXe siècle [Online], 5 | 1989, Online since 09 September 2008, connection on 03 May 2019. URL : http:// journals.openedition.org/rh19/32 ; DOI : 10.4000/rh19.32

This text was automatically generated on 3 May 2019.

Tous droits réservés 


\title{
1830-1930 : le centenaire des Trois glorieuses en France
}

\author{
Fernand Rude
}

\section{ABSTRACTS}

No abstract available by now

Pas de résumé disponible actuellement

INDEX

Mots-clés: Trois glorieuses, Commémoration 